\title{
ФОРМИ КРИМІНОЛОГІЧНОї ДІЯЛЬНОСТІ ЕКСПЕРТНИХ УСТАНОВ
}

\author{
ФІЛІШЕНКО Наталія Свгенівна - кандидат юридичних наук, доцент (доценТ \\ кафедри права Національного аерокосмічного університету ім. М. Є. Жуковського \\ «Харківський авіаційний інститут»)
}

Orcid:https://orcid.org/0000-0001-9469-3650

УДК 343.9

DOI 10.32782/LAW.UA.2020.3.23

В статъе рассматриваются формъг экспертной пробилактики: процессуальная и непрочессуальная. Процессуальная форма реализуется во время проведения экспертизы повопросам пробилактического характера, использования права эксперта на инициативу,участия эксперта в следственных действиях в качестве спешиалиста, осмотре места происшествия и следственном эксперименте. Непроцессуальная борма состоит в обобщении экспертной практики, проведении научнъгх исследований повопросам экспертной пробилактики, проведении разъяснительной работь и предоставлении практической помощи при реализащии пробилактических мер.

Ключевъе слова: преступность, профилактика, эксперт, экспертиза, экспертная инициатива, бормъ экспертной пробилактики.

Постановка проблеми

Основним напрямком діяльності держави і суспільства у боротьбі зі злочинністю $є$ вжиття заходів щодо попередження ще не вчиненого, але можливого суспільно небезпечного прояву. Саме попереджувальна діяльність надає можливість усунути всі можливі потенційні загрози та забезпечити дотримання прав та свобод громадян, інтереси суспільства та держави. Якраз на цьому безпосередньо акцентує увагу і кримінальний закон, зазначаючи, що його основним завданням $є$ правове забезпечення охорони, а також запобігання кримінальним правопорушенням.
У той же час, реформування правоохоронної системи призводить до певного ігнорування вищевказаного завдання суб'єктами протидії злочинності внаслідок недосконалості законодавства та «вимивання» професіоналів 3 лав правоохоронних органів. Тому актуальною на сьогодні постає проблема залучення додаткових сил та засобів у протидії злочинності, у тому числі, шляхом використання спеціальних знань.

Питанням експертної профілактики в цілому присвячені роботи таких науковців криміналістів, як I.A. Алієв, P.С. Бєлкін, Ф.Е. Давудов,В.П. Колмаков, Ю.Г. Корухов, Ю.К. Орлов,Б.І. Пінхасов, І.Я. Фрідман, О.Р. Шляхов та ін., проте, враховуючи сучасні зміни в кримінально-процесуальне законодавство робіт, безпосередньо присвячених дослідженню форм та способів фіксації експертної профілактики, останнім часом не публікувалося. Зазначене потребує окремої уваги в питаннях дослідження змісту та форм кримінологічної діяльності експертних установ у сучасних умовах.

Мета дослідження: дослідити особливості кримінологічної діяльності експертних установ, визначити ії форми та зміст.

Завдання дослідження полягає в аналізі чинного законодавства та сучасних позицій науковців щодо форм експертної профілактики та способів ії фіксації у сучасних умовах. 


\section{Кримінальне право, кримінальний процес та криміналістика}

\section{Основний текст}

Протидія злочинності, будучи динамічною діяльністю, цілком логічно зумовлює необхідність звернення до основних положень правової доктрини щодо форм і методів ії здійснення.

У кримінології під формами попереджувальної діяльності розуміють науково обгрунтовану систему найбільш доцільних засобів вирішення завдань профілактики злочинів [1, с. 118].

У криміналістиці діяльність експерта традиційно поділяється на процесуальну та непроцесуальну форми [2, с. 12-13; 3, с. $26-28$; 4, с. 79-83; 5, 97-99; 6, с. 192-195; 7, 18-20]. Пов'язується це з тим, що більшу частину своїх повноважень судовий експерт реалізує через встановлений та закріплений у законодавстві процесуальний порядок. Основною формою взаємодії експерта зі слідчим та суддею є проведення відповідної експертизи, що полягає у з'ясуванні, на підставі спеціальних знань, обставин, які мають значення для кримінального провадження (ст. 242 КПУ України). Порядок та підстави такого залучення врегульовані 243-244 КПК України.

Дані експертиз використовуються в попередженні злочинів та інших правопорушень у межах криміналістичної і кримінологічної профілактики для цілей кримінального і цивільного процесів, з адміністративних і господарських справ тощо [8, с. 44]. Це викликано тим, що профілактична діяльність експертних установ пов'язується не лише зі сферою кримінально-правових відносин. Суспільна небезпечність притаманна як кримінальним, так іадміністративним та цивільним правопорушенням, причому межа між ними у ряді випадків надто відносна: за одне і те ж правопорушення в один період законодавець передбачає кримінальну відповідальність, у другий - тільки адміністративну. При розгляді цивільних і адміністративних проваджень можуть бути встановлені такі фактичні обставини (недоліки окремих правил і інструкцій, дефекти виробів i матеріалів), які не є правопорушеннями, проте їх усунення дозволить попередити можливість настання аварії або нещасного випадку, вдосконалити визначену дільницю виробничої діяльності, отримати економічний ефект. В усіх цих випадках можуть бути використані у профілактичних цілях дані експертиз. У першу чергу, це стосується тих цивільних справ, за якими як докази фігурують документи (банківські перекази, бухгалтерські та нотаріальні документи тощо). За позовами про відшкодування шкоди, пов'язаної з порушенням техніки безпеки, дорожньо-транспортними пригодами і пошкодженнями майна призначаються судово-хімічні, товарознавчі, автотехнічні й інші експертизи, з господарських справ - трасологічні, при проведенні яких можуть бути встановлені обставини, що мають значення для попередження правопорушення [8, с. 43].

Цивільним процесуальним та кримінальним процесуальним законодавством також передбачений такий вид діяльності, як експертна ініціатива. Відповідно до ч. 4 ст. 69 КПК України експерт має право викладати у висновку експертизи виявлені в ході їі проведення відомості, які мають значення для кримінального провадження i 3 приводу яких йому не були поставлені запитання, що означає можливість напряму рекомендувати профілактичні заходи з запобігання окремим видам злочинних посягань 3 урахуванням отриманих висновків експертизи.

Статтею 71 КПК України також передбачений процесуальний порядок та випадки залучення експерта спеціаліста у кримінальному впровадженні, в тому числі під час огляду місця події (ст. 273 КПК України), інших слідчих діях, зокрема слідчому експерименті (ст. 240 КПК України) або негласних слідчих діях (ст. 246 КПК України).

Слід зазначити, що окремими науковцями висловлюеться сумнів щодо процесуальної діяльності спеціаліста, вказуючи на їі технічний характер [9, с. 125]. Однак як зазначають автори монографії «Профілактика правопорушень (кримінологічні та експертнокриміналістичні аспекти)»: «...разом 3 тим залучення спеціаліста до проведення слідчих дій носить процесуальний характер, хоч і в цьому випадку його повідомлення щодо профілактики правопорушень (як і експерта) підлягають оцінці слідчого і суду, 
які можуть 3 висловленими думками не погоджуватись. Aле і в усіх цих випадках доказові факти, що породжуються, якщо ця діяльність здійснюється відповідно до процесуального закону, оцінюються слідчим і судом» [8, с. 80-81].

Велике значення для всієї діяльності щодо попередження кримінальних та інших правопорушень мають непроцесуальні форми виявлення і застосування заходів до усунення умов, що сприяли їх скоєнню. Відповідно до покладених на них обов'язків експертні служби здійснюють аналітичну діяльність, складають статистичну звітність, узагальнюють експертну практику [10]. Зокрема, відповідно до п. 1.6.2. Наказу МВС УкраїниN 390 від 10.09.2009 «Про затвердження Інструкції з організації функціонування криміналістичних обліків експертної служби МВС», створення експертними службами на відповідному рівні інформаційно-довідкових колекцій призначено для використання об'єктів, уміщених до них, у тому числі, 3 метою узагальнення відомостей про причини й умови вчинення злочинів та інших правопорушень $з$ метою запобігання їм.

Про важливе значення узагальнень експертної практики наголошувалось у Наказі міністра юстиції СРСР № 11 від 27 червня 1985 року «Про підвищення ролі судовоекспертних закладів у профілактиці правопорушень»: широке розповсюдження отримала практика узагальнення експертних досліджень за окремими категоріями кримінальних і цивільних справ у цілях виявлення найбільш типових причин і умов виникнення правопорушень і розробки мір щодо їх усунення. Узагальнення експертних досліджень можуть проводитися за об'єктами досліджень, за окремими видами експертиз, виробничими та територіальними одиницями, відповідними категоріями проваджень кримінальні, цивільні, адміністративні.

За результатами проведених узагальнень підготовлюються повідомлення (інформації) у правоохоронні органи, господарським суб'єктам i службовим особам, від яких залежить прийняття мір щодо усунення виявлених обставин. На жаль, слід констатувати недостатній рівень зазначеної форми профілактики у сучасних умовах. Як показує практика, в більшості експертних установах узагальнення практики не проводиться взагалі або нерегулярно [8, с. 85].

Проведення узагальнення, як правило, повинно пов'язуватися 3 науково-дослідною тематикою. Науково-дослідна робота, базуючись як на експериментальних розробках, так і на узагальненнях експертної і слідчої та судової практики, направлена на виявлення обставин, сприяючих чи полегшуючих здійснення і приховування злочинів, $\mathrm{E}$ непроцесуальною формою профілактичної діяльності. Організація науково-методичного забезпечення судово-експертної діяльності та організаційно-управлінські засади діяльності державних спеціалізованих установ,що здійснюють судово-експертну діяльність, покладаються на міністерства та інші центральні органи виконавчої влади, до сфери управління яких вони належать (ст. 8 закону України «Про судову експертизу»). Відповідно до ст. 4 Положення про Експертну службу Міністерства внутрішніх справ України, Експертна служба МВС здійснює організаційно-управлінське та науковометодичне забезпечення судово-експертної діяльності, у тому числі розробляє методики проведення судових експертиз, стандарти, технічні регламенти, державні класифікатори, методичні рекомендації, довідкові посібники, програмні продукти. За результатами та наслідками цих наукових досліджень можуть бути запропоновані різні рекомендації профілактичного характеру, в тому числі розроблені спеціальні науково-технічні засоби, що запобігають доступу стороннім особам у сховище товарно-матеріальних цінностей, які фіксують їх перебування там, тощо [8, с. 88].

Непроцесуальними формами профілактичної роботи є також надання науковопрактичної допомоги державним органам i громадським організаціям у виявленні обставин, які сприяють) здійсненню злочинів, та інших правопорушень (шляхом надання консультацій і роз'яснень, читання лекцій, проведення виховних та роз'яснювальних бесід, інструктажів, участь у перевірках тощо), ознайомлення співробітників правоохоронних органів 3 можливостями судових експертиз у виявленні цих обставин. 


\section{Кримінальне право, кримінальний процес та криміналістика}

\section{Висновки}

Таким чином, до процесуальної форми кримінологічної діяльності експертних установ належать:

1) проведення експертизи із встановлення обставин, що сприяли скоєнню правопорушення (проведення експертизи 3 питань профілактичного характеру);

2) встановлення обставин, що мають значення для попередження правопорушень за власною ініціативою експерта (використання права експерта на ініціативу);

3) участь експерта у слідчих діях як спеціаліста;

4) участь в огляді місця події та слідчому експерименті;

5) консультації спеціаліста щодо припинення злочинів іноді можуть надаватися спеціалістом у процесі проведення оперативно-розшукових заходів (наприклад, рекомендації щодо фотографування оперативним шляхом безтоварних документів).

До непроцесуальної форми профілактичної діяльності співробітників експертних установ належить:

1) узагальнення експертної, судової й слідчої практики;

2) проведення наукових досліджень 3 питань експертної профілактики;

3) надання на основі спеціальних знань науково-практичної допомоги державним та громадським організаціям у виявленні обставин, що мають значення для профілактики правопорушень;

4) надання практичної допомоги у здійсненні профілактичних заходів в органах нотаріату, соціальної допомоги населенню та підприємцям;

5) проведення роз'яснювальної роботи (лекції, семінари, інструктажі тощо) для певних аудиторій або широких кіл громадськості.

Слід констатувати, що експертна профілактика пов'язана з усіма напрямами діяльності експертних установ і може здійснюватися в різноманітних формах, зокрема за конкретними експертизами, при узагальненнях експертної практики, розробці науково-дослідницької тематики, проведенні методичної роботи і правової пропаганди тощо.У зв'язку з цим не повинна виклика- ти заперечень теза про можливість і закономірність використання спеціальних пізнань співробітників експертних установ у профілактичній роботі щодо попередження злочинів та інших правопорушень. Форма такого використання спеціальних знань у кримінальному провадженні вже апробована практикою, а в окремих випадках передбачена законодавством у вигляді нормативно закріпленої системи правил застосування під час досудового розслідування та судового розгляду спеціальних знань уповноважених законом осіб.

\section{Аітература}

1. Кримінологія: підручник / за заг ред.^. С. Сміяна, Ю. В. Нікітіна. Київ: Національна академія управління, 2010. 496 с.

2. Навчально-методичний посібник для самостійної роботи та практичних занять 3 навчальної дисципліни «Експертна профілактика» (галузь знань 0304 «Право», освітньо-кваліфікаційний рівень «Магістр», спеціальність 8.18010003 «Судова експертиза») / уклад.: В. А. Журавель, В. О. Коновалова, В. Ю. Шепітько та ін. Харків: Нац. ун-т «Юрид. акад. України ім. Ярослава Мудрого», 2012. 22 c. URL: http://dspace.nlu.edu.ua/ bitstream/123456789/668/1/NMP 0069.pdf (дата звернення 12.11.2020).

3. Колмаков В. П. О формах и методах деятельности экспертных учреждений по предупреждению хищений государственного и общественного имущества // Вопросы судебной экспертизы. Азерб. НИИСЭ. Баку, 1965. Вып. 1. С. 25-29.

4. Палиашвили А. Я. Формы профилактической деятельности судебно-экспертных учреждений // Вопросы судебной экспертизы. - Баку, 1965. Вып. 1. С. 79-83.

5. Фридман И. Я. Использование специальных познаний в работе по предупреждению преступлений // Криминалистика и судебная экспертиза. Киев, 1964. Вып 1. С. 97-99. 6. Фридман И. Я. Использование криминалистической экспертизы документов для предупреждения преступлений. // Использование научных методов и технических средств в борьбе с преступностью. Минск: Изд. «Полымя», 1965. С. 192-195. 


\section{АНОТАЦІ}

у статті розглядаються форми експертної профілактики: прочесуальна $і$ непрочесуальна. Прочесуальна борма реалізується під час проведення експертизи з питань проббілактичного характеру, використання права експерта на ініціативу, участі експерта в слідчих діях як спеціаліста, огляді місия подї̈ $і$ слідчому експерименті. Встановлено важливість та необхідність використання даних, отриманих у процесі проведення експертиз для попередження злочинів та інших правопорушень як для иілей кримінального, так $і$ ицвільного процесів, з адміністративних $i$ господарсъких справ.Зазначена бборма передбачає безпосереднє залучення експерта до прочесуальних дій на підставі відповідного рішення органу дізнання, слідчого, прокурора або суду. Визначено права та обов'язки експерта у иивільному прочесуальному та кримінально-прочесуальному законодавстві стосовно здійснення пробілактичної діяльності 3 попередження кримінальних правопорушень. Непроцесуальна форма участі експерта в пробілактичній діяльності складається з узагальнення експертної практики, проведення наукових досліджень з питань експертної пробілактики, роз'яснювальної роботи та надання практичної допомоги при реалізацї пробілактичних заxodis.

Зазначено недоліки законодавчої регламентащиі процесуальної та непрочесуальної борм кримінологічної діяльності експертних установ, зокрема низъкий рівень узагальнення експертної практики та розроблення рекомендаиій правоохоронним органам та іншим суб'єктам протидї злочинності з питань проббілактичной діяльності. Розроблені пропозиий щодо вдосконалення законодавчого механізму профілактичної діяльності експертних установ.

Ключові слова: злочинність, проббілакти$\kappa a$, експерт, експертиза, експертна ініціатива, борми експертної пробілактики.

7. Шляхов А.Р. Правовые основания, формы и методы профилактической деятельности эксперта и экспертного учреждения // Вопросы судебной экспертизы. Баку, 1965. Вып. 1. С. 18-20.

8. Профілактика правопорушень (кримінологічні та експертно-криміналістич-

\section{SUMMARY}

The article considers the forms of expert prevention: procedural and non-procedural. Procedural forms implemented during the examination on the preventive use of legal experts on the initiative, participation of experts in the investigation as a specialist, inspection of the scene and investigators experiment. The importance and necessity of using the data obtained in the process of examinations to prevent crimes and other offenses for the purposes of not only criminal but also civil proceedings, administrative and commercial cases. These forms provides direct involvement of experts to proceedings under the relevant decision of the inquiry agency, investigator, prosecutor or court. Defined rights and duties of an expert in civil procedural and criminal procedural law in respect of the implementation of prevention activities to prevent criminal offenses. Non-processual form of participation of experts in preventive activities consist of summarizing the expert practice, research on peer prevention, advocacy and practical assistance in the implementation of preventive measures.

The shortcomings of the legislative regulation of procedural and non-procedural forms of criminological activity of expert institutions are noted, in particular the low level of generalization of expert practice and development of recommendations to law enforcement bodies and other subjects of counteraction to crime on preventive activities. Proposals for improving the legislative mechanism of preventive activities of expert institutions have been developed.

Keywords: crime, prevention, expert, expertise, expert initiative, forms of expert prevention.

ні аспекти): монографія / П. В. Мельник, Н. О. Данкович, І. Я. Фрідман, та ін. Ірпінь: Національний університет ДПС України, 2011. 170 c.

9. Зуев Е. И. Познания сведущего лица в предупреждении преступлений // Вопросы судебной экспертизы. Баку, 1973. Вып. 16. С. 125-131.

10. Наказ МВС України № 1343 від 03.11.2015 «Про затвердження Положення про Експертну службу Міністерства внутрішніх справ України». URL: https://zakon. rada.gov.ua/laws/show/z1390-15\#Text(дата звернення 12.11.2020). 